BMC

Immunology

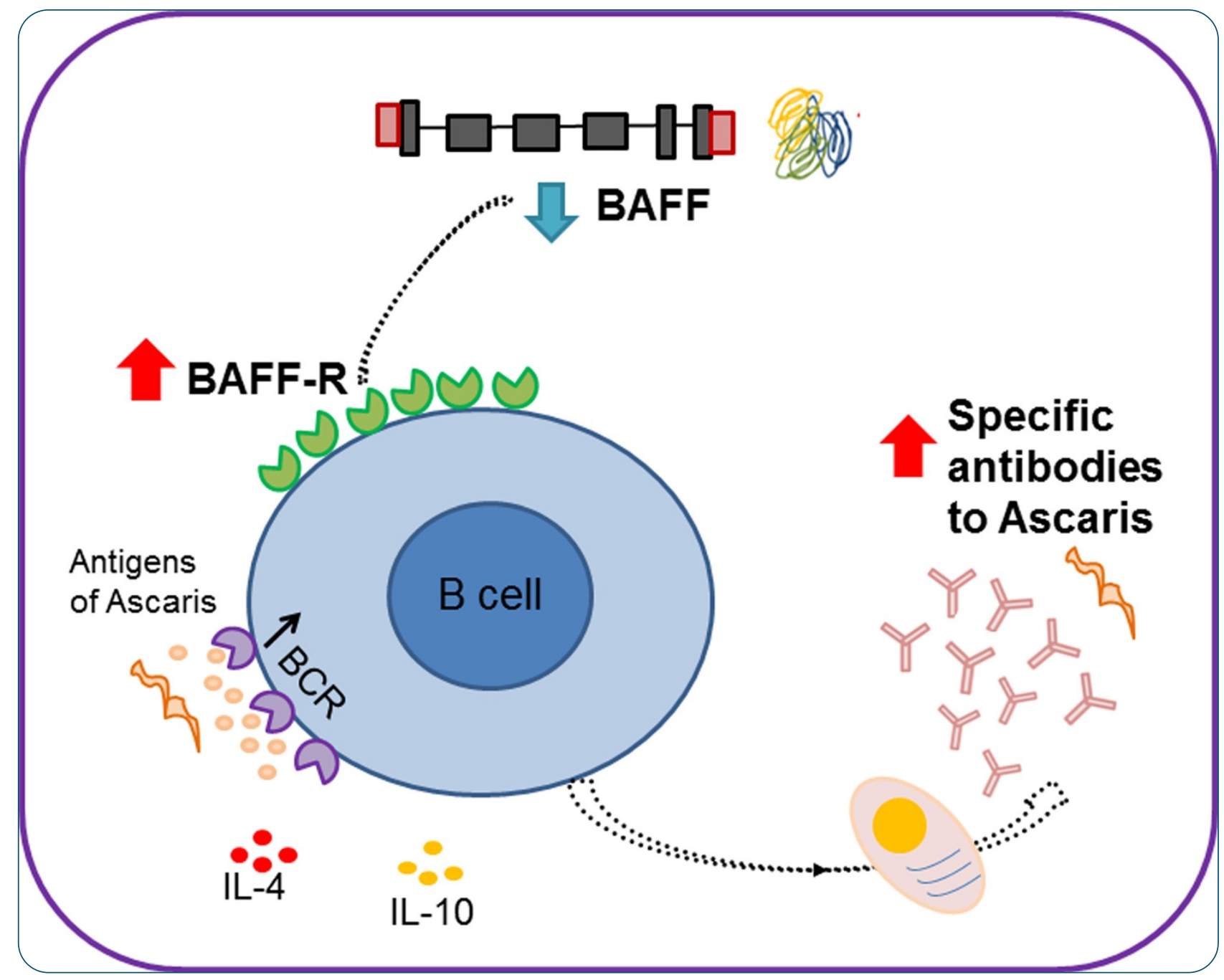

The strength of the antibody response to the nematode Ascaris lumbricoides inversely correlates with levels of B-Cell Activating Factor (BAFF)

Bornacelly et al.

() Biomed Central

Bornacelly et al. BMC Immunology 2014, 15:22 


\title{
The strength of the antibody response to the nematode Ascaris lumbricoides inversely correlates with levels of B-Cell Activating Factor (BAFF)
}

\author{
Adriana Bornacelly ${ }^{1,2}$, Dilia Mercado ${ }^{1}$, Nathalie Acevedo ${ }^{1,2}$ and Luis Caraballo $0^{1,2^{*}}$
}

\begin{abstract}
Background: B-Cell Activating Factor (BAFF) is a cytokine regulating antibody production. Polymorphisms in the gene encoding BAFF were associated with the antibody response to Ascaris but not to mite allergens. In the present study we evaluated the relationship between BAFF and specific antibodies against Ascaris and mites in 448 controls and 448 asthmatics. Soluble BAFF was measured by ELISA and BAFF mRNA by qPCR. Surface expression of BAFF and its receptor (BAFF-R) was analyzed by flow cytometry.

Results: Individuals with specific IgE levels to Ascaris >75th percentile had lower levels of soluble BAFF; those with specific lgG levels to Ascaris $>75$ th percentile had reduced BAFF mRNA. Total IgE and specific IgE to mites were not related to BAFF levels. There were no differences in soluble BAFF or mRNA levels between asthmatics and controls. There was an inverse relationship between the cell-surface expression of BAFF-R on CD19 ${ }^{+}$B cells and BAFF levels at the transcriptional and protein level.
\end{abstract}

Conclusions: These findings suggest that differences in BAFF levels are related to the strength of the antibody response to Ascaris.

Keywords: Ascaris, Antibodies, Asthma, BAFF, BAFF-R, lgE, IgG, Immune response, Nematode, Parasite

\section{Background}

Infection by Ascaris lumbricoides (ascariasis) is one of the most prevalent helminthic diseases, affecting about 1.5 billion people worldwide. The immune response to this nematode has as hallmarks the induction of anti-Ascaris IgE/IgG antibodies and a strong Th2-driven inflammation [1]. Specific antibodies to Ascaris have been associated to parasite resistance [2-5] and both the immunoglobulin repertoire as well as the strength of the antibody responses are genetically regulated [6]. In mice, the production of IgE to the Ascaris resistance marker ABA-1 is HLA restricted [7]. In humans, two linkage scans identified a QTL (Quantitative Trait Loci) on chromosome 13q33.3 associated with the susceptibility to $A$. lumbricoides $[8,9]$. This region harbors the gene TNFSF13B (Tumor Necrosis Factor Ligand Superfamily, member 13b) encoding for the

\footnotetext{
* Correspondence: Icaraballog@unicartagena.edu.co

'Institute for Immunological Research, University of Cartagena, Cra 5, \#7-77, 13-0015 Cartagena, Colombia

${ }^{2}$ Foundation for the Development of Medical and Biological Sciences (Fundemeb), 13-0001 Cartagena, Colombia
}

cytokine B-Cell Activating Factor, BAFF. The wild type allele of an intronic polymorphism in this gene (rs10508198) was found associated with higher IgG levels against Ascaris while the mutant allele was associated with less IgE to ABA-1 in asthmatics patients [10] suggesting a role of TNFSF13B in the antibody response to Ascaris.

BAFF (also known as BlyS, CD257), is a member of the tumor necrosis factor ligand superfamily of cytokines and is a major regulator of B cell activation, proliferation, differentiation, survival and immunoglobulin class-switching [11-13]. It is mainly expressed in innate immune cells such as neutrophils, macrophages and dendritic cells $[14,15]$ but is also produced by non-hematopoietic cells $[16,17]$. This molecule may exist as cell surface-bound or soluble forms, the latter secreted after a furin cleavage $[18,19]$. Soluble BAFF interacts with three receptors: TACI (transmembrane activator and calcium-modulating cyclophilin ligand interactor), BCMA (B cell maturation antigen) and BAFF-R (BAFF receptor or BR3), the latter expressed on peripheral B cells $[20,21]$. In vitro experiments have demonstrated the critical role of BAFF on the production of 
IgA and IgG antibodies and the synergic effect with IL-4 on the transcription of IgE [22]. In these processes the BAFF-R also plays an important role [23,24].

Changes in BAFF levels are detectable in plasma during different immune related conditions [16]. In addition, there is evidence that upon nematode infection, resistant animals have increased levels of BAFF. In cattle naturally exposed to Ostertagia, Cooperia and Nematodirus the parasiteresistant animals had increased BAFF mRNA levels in the mesenteric lymph nodes [25]. High BAFF mRNA expression have been also detected in the spleen and liver of red grouse infected with Trichostrongylus tenuis [26]. Further studies in protozoan infections found that BAFF might be associated to variations in the strength of specific antibodies; for instance, administration of an antibody blocking BAFF signaling in mice infected with Trypanosoma cruzi induced a significant reduction of serum specific-IgM to the parasite [27]. Besides, there is evidence that Plasmodium parasites can modulate the BAFF pathway in the host, compromising protective antibody memory [28]. Although these investigations suggest that TNFSF13B may be a candidate gene underlying phenotypic variation in response to parasite infections, few have been done in humans. There are no studies evaluating the role of BAFF on the strength of Ascaris specific antibody production or total IgE in humans naturally exposed to this parasite. Since it has been observed that asthmatics have a higher antibody response to nematodes [29], these individuals are an interesting group for analyzing these traits. The aims of this study were (a) to investigate the relationship between
BAFF and specific antibody levels to Ascaris, (b) to evaluate the relationship between BAFF and total IgE and specific IgE to non-parasitic allergens in asthmatic patients and non-asthmatic controls and (c) to evaluate the relationship between BAFF levels and the cell-surface expression of its receptor (BAFF-R) on CD $19^{+}$B cells.

\section{Results and discussion}

\section{BAFF and the antibody response to Ascaris}

The demographical characteristics and antibody responses of the studied population are presented in Table 1 . In the entire dataset $(n=896)$, BAFF values in plasma were nonnormally distributed with median $792.1 \mathrm{pg} / \mathrm{ml}$ (interquartile range 594.2-978.7 pg/ml) Figure 1A. There were no differences in soluble BAFF levels according to age, gender or disease status. IgE to Ascaris was higher in asthmatic patients while IgG to Ascaris was higher in controls and total serum IgE was higher in asthmatics (Table 1).

The relationship between levels of soluble BAFF and antibodies to Ascaris was first evaluated using bivariate correlations stratified by healthy and asthmatics. Because soluble BAFF and the specific IgE levels to Ascaris were nonnormally distributed, the non-parametric Spearman test was used. We found a significant inverse correlation between soluble BAFF and specific IgE to Ascaris $(\mathrm{r}=-0.10$, $\mathrm{p}=0.03)$ in the group of healthy individuals $(\mathrm{n}=448)$. A similar tendency was observed when comparing soluble BAFF levels between subjects with positive IgE sensitization to Ascaris ( $\mathrm{OD} \geq 0.113, \mathrm{n}=392$ ) and those non-sensitized $(\mathrm{n}=425)$ : soluble BAFF was lower in Ascaris sensitized

Table 1 Descriptive of the study population

\begin{tabular}{|c|c|c|c|}
\hline Variables & Asthmatic patients $(n=448)$ & Non-asthmatic controls $(n=448)$ & p-value \\
\hline Age, years (Mean $\pm S D$ ) & $34.4 \pm 18.2$ & $36.7 \pm 18.6$ & 0.06 \\
\hline Gender, female, n (\%) & $256(57.1)$ & $249(55.6)$ & 0.6 \\
\hline Soluble BAFF levels $[\mathrm{pg} / \mathrm{ml}]^{a}$ & $768(554.2-999.1)$ & $804.3(628.5-964.3)$ & $0.16^{\mathrm{b}}$ \\
\hline mRNA levels BAFF1 ${ }^{c}$ (Mean $\left.\pm \mathrm{SD}\right)$ & $3.21 \pm 1.39$ & $3.12 \pm 1.14$ & $0.6^{d}$ \\
\hline mRNA levels BAFF2 ${ }^{\complement}$ (Mean $\pm \mathrm{SD}$ ) & $2.79 \pm 1.04$ & $2.70 \pm 0.94$ & $0.5^{d}$ \\
\hline Total lgE, UI/ml $\left.\right|^{a, e}$ & $699.7(236.3-1065.8)$ & $148.8(58.3-408.1)$ & $<0.001^{b}$ \\
\hline \multicolumn{4}{|l|}{ Ig levels to parasite $(O D)^{a, e}$} \\
\hline slgE to Ascaris & $0.117(0.100-0.150)$ & $0.105(0.091-0.134)$ & $<0.001^{b}$ \\
\hline slgG to Ascaris & $1.99(1.60-2.34)$ & $2.17(1.73-2.69)$ & $<0.001^{b}$ \\
\hline slgE to $A B A-1$ & $0.125(0.098-0.187)$ & $0.119(0.099-0.154)$ & $0.18^{b}$ \\
\hline slgG to $A B A-1$ & $1.49(1.09-1.83)$ & $1.70(1.36-2.11)$ & $<0.001^{\mathrm{b}}$ \\
\hline \multicolumn{4}{|l|}{ Ig levels to HDM (OD) ${ }^{\mathrm{a}, \mathrm{e}}$} \\
\hline IgE to D. pteronyssinus & $0.191(0.115-0.520)$ & $0.099(0.089-0.122)$ & $<0.001^{\mathrm{b}}$ \\
\hline IgE to B. tropicalis & $0.231(0.110-1.06)$ & $0.098(0.089-0.122)$ & $<0.001^{\mathrm{b}}$ \\
\hline
\end{tabular}

SD: Standard deviation.

${ }^{a}$ Median (Inter Quartile Range).

${ }^{\mathrm{b}}$ Mann-Whitney $\mathrm{U}$ test.

${ }^{c}$ Measured in PBMCs ( $n=131$, including 71 asthmatics and 60 controls).

${ }^{d}$ Independent samples t-test.

eData available only for 369 asthmatics. 
A

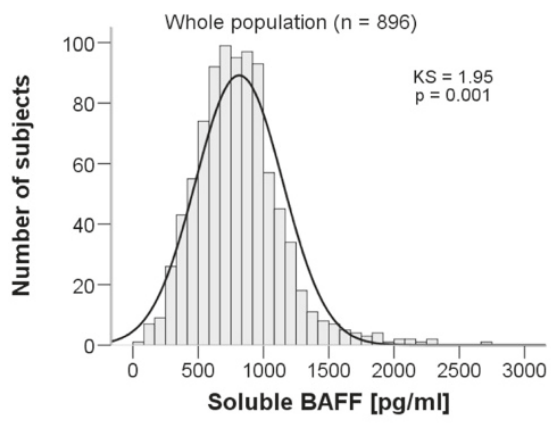

B

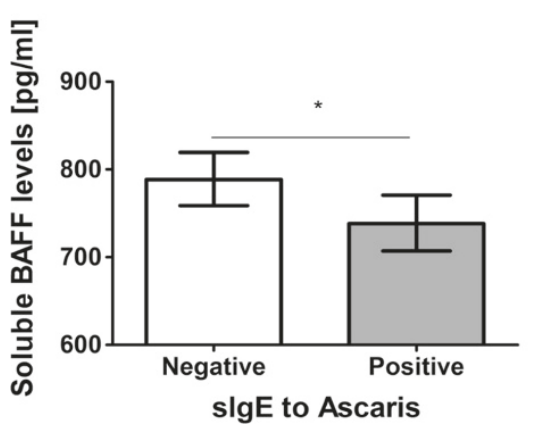

C

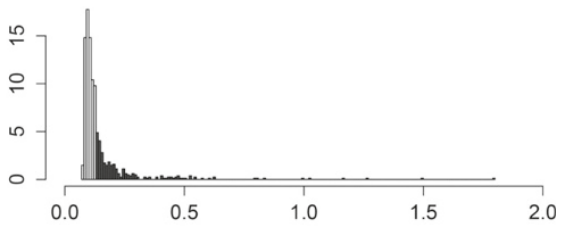

$\overline{\bar{\varepsilon}}$
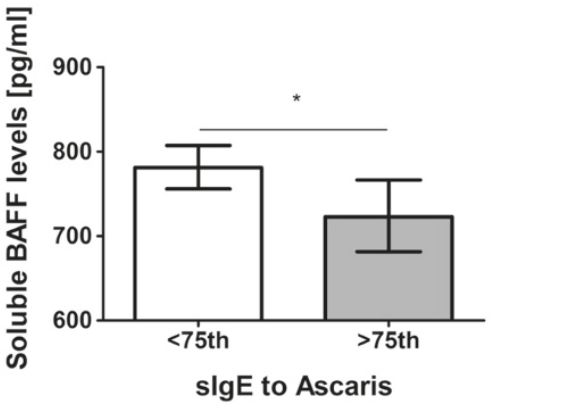

Figure 1 BAFF levels according to the IgE antibody response to Ascaris. A. Distribution of soluble BAFF levels in the population; KS: Kolmogorov-Smirnov B. Soluble BAFF levels in individuals with negative $(n=425)$ or positive $(n=392)$ IgE to Ascaris $\mathbf{C}$. Distribution of specific lgE to Ascaris; density (y-axis), optical density units (x-axis), shaded bars represent individuals with levels $>75$ th percentile (upper panel). Soluble BAFF levels between individuals with specific IgE levels to Ascaris below $(n=583)$ and above $(n=234) 75$ th percentile (lower panel). All lines indicate geometric mean $(95 \% \mathrm{Cl})$, * $\mathrm{p}<0.05$.

(median 786.3 pg/ml; IQR 595.1-973.6) than in nonsensitized (829.6 pg/ml; IQR 653.3-1013, Mann-Whitney $\mathrm{U}$ test, $\mathrm{p}=0.03)$, Figure $1 \mathrm{~B}$.

Considering that parasite loads are over-dispersed within populations [30] and that individuals at the extreme of the distribution might carry biological traits influencing parasite susceptibility, we analyzed the relationship between soluble BAFF and the strength of the antibody response by stratifying the participants according their antibody levels, above 75 th percentile $(>75$ th) and below 75 th percentile (<75th), Figure 1C (upper panel). We found that those with high specific IgE levels to the Ascaris extract ( $\mathrm{n}=$ 234) had less concentrations of soluble BAFF in plasma (median 786.3 pg/ml; IQR 573.8-985) than those with IgE levels $<75$ th percentile $(\mathrm{n}=583$, median $819.7 \mathrm{pg} / \mathrm{ml}$; IQR 653.6-991.3; Mann-Whitney $U$ test $p=0.04)$, Figure $1 C$. This association remained significant in the linear regression model using the square-root transformed soluble BAFF levels, and after adjustment by age, gender and disease status $(p=0.028)$. To explore if this relationship was reflected at the gene expression level, we analyzed a subgroup of subjects $(n=131)$ with mRNA data in peripheral blood mononuclear cells (PBMCs), but we found no association between the relative expression of $B A F F$ mRNA and specific IgE levels to Ascaris (data not shown).
Besides, there was no significant correlation between soluble BAFF levels and IgG levels to Ascaris using nonparametric tests. Since IgG levels were normally distributed, we tested a more powerful parametric test (Pearson's $r$ ) using square-root-transformed soluble BAFF levels, with similar results. Interestingly, there was a significant inverse correlation between $B A F F$ mRNA levels and IgG to Ascaris $(\mathrm{r}=-0.22, \mathrm{p}=0.01)$, Figure 2A. This relationship was also observed when the comparison was done according to the strength of the antibody response: individuals with specific IgG levels to Ascaris $>75$ th percentile had lower BAFF1 mRNA levels $(\mathrm{n}=40$, mean $2.68 \pm 1.0 \mathrm{SD})$ than those $<75$ th percentile $(n=91$, mean $3.38 \pm 1.3 \mathrm{SD}$, $\mathrm{p}=0.003$ ), Figure 2B.

The relationship between BAFF and serum antibody levels has been extensively analyzed in the context of autoimmune diseases, where increased levels of soluble BAFF have been associated with increased titers of auto-antibodies of the IgG isotype [11,31-34]. However, the effects of BAFF on specific antibody levels may differ depending on the context, for instance, inverse relationships between $B A F F$ mRNA levels and the risk of developing donor-specific antibodies have been observed after transplantation [35]. To our knowledge this is the first study suggesting a relationship between circulating BAFF 


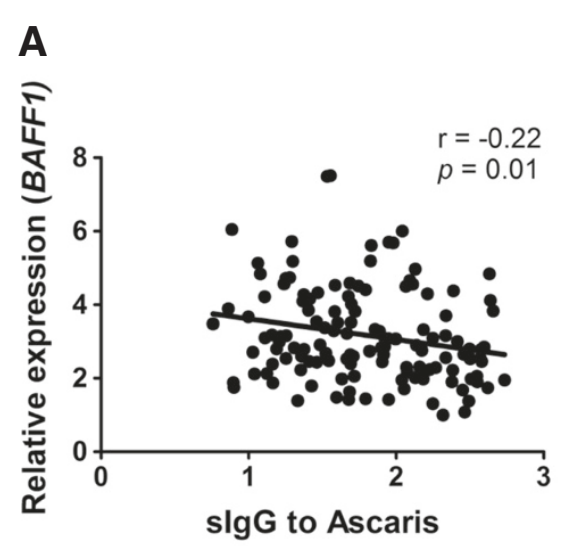

B
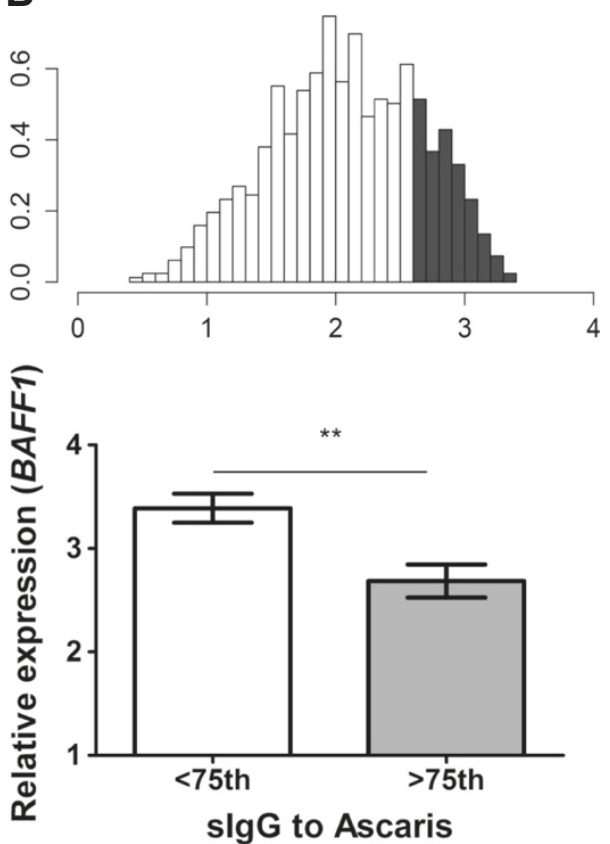

Figure 2 BAFF mRNA levels according to the specific IgG to Ascaris. A. Correlation between the mRNA expression for BAFF1 and the levels of specific lgG to Ascaris. The numbers indicate the Pearson correlation coefficient ( $r$ ) and the $p$-value (two-tailed); each dot represents an individual B. Distribution of specific lgG levels to Ascaris; density (y-axis), optical density units ( $\mathrm{x}$-axis), shaded bars represent individuals with lgG levels $>75$ th percentile (upper panel); BAFF1 mRNA levels between individuals with IgG to Ascaris below $(n=91)$ or above $(n=40) 75$ th percentile (lower panel), ${ }^{* *} p<0.005$.

levels and the human antibody response to a nematode. In contrast to what is generally observed in autoimmune diseases and some parasitic infections, we found an inverse association between soluble BAFF and the strength of the antibody response to Ascaris. The fact that the same tendency was observed both at protein and mRNA level is highly suggestive that it represents a biological phenomenon. The mechanisms underlying this relationship are unknown.

The mean difference in soluble BAFF levels between subjects with high specific IgE to Ascaris and the rest of the population was $52 \mathrm{pg} / \mathrm{ml}$. The biological significance of this finding need to be further investigated but there are several studies suggesting that it could be relevant. It has been shown that most of the systemic BAFF is bound to receptors on B cell surfaces and that BAFF binding capacity on follicular B cells is nearly saturated under steady-state conditions in vivo [36]. In this scenery a small change in circulating BAFF concentrations may affect the BAFF balance in lymphoid tissues and impair the survival of high-affinity $B$ cells clones in the germinal center. In addition, it is known that for some cytokines the biological impact is in the order of few $\mathrm{pg} / \mathrm{ml}$; for example, concentrations of IFN $\gamma$ between healthy and malaria infected children differ in $8.1 \mathrm{pg} / \mathrm{ml}$, and this small change correlated with soluble BAFF levels and concentration of antibodies [37].
Moreover, differences in cytokine levels upon stimulation of PBMCs with phytohemagglutinin or Ascaris were small but the impact on antibody production was remarkable [38]. Differences in levels of pro-inflammatory cytokines between healthy individuals and patients with autoimmune conditions have been also described in this range [39].

Previous studies showed that TNFSF13B gene is a QTL for Ascaris susceptibility [8,9], harboring genetic variants associated with IgE response to Ascaris and worm burden $[10,40]$. Now we have data suggesting that, in addition to genetic evidence, there is a relationship between the antibody responses to Ascaris and BAFF at the protein and mRNA level; although a causal relationship between them has yet to be demonstrated. Our findings seem to be more related to genetic mechanisms because first, there is previous evidence suggesting that polymorphisms around TNFSF13B may influence the antibody responses and second, we also found an association between the IgG responses and the level of mRNA expression. It is also pertinent to consider that $A$. lumbricoides can modify BAFF levels during infection, as has been reported for malaria parasite in acutely infected children [37]. However, in our study it is not possible to assess a direct effect of the parasite on BAFF production because it was designed to evaluate the antibody responses to Ascaris and not the acute infection. Besides, we should keep in mind that low BAFF 
levels and high antibody responses might be independent consequences of the Ascaris infection without any causal relationship. Indeed, IL-4 has shown to down-regulate the expression of BAFF in vitro [41]. It is known that Ascaris infections of low intensity are associated with a Th2 immune response rich in IL-4 and in this population this could be an additional factor introducing variability in BAFF levels.

\section{Soluble BAFF, total IgE, specific IgE and asthma}

The relationship between BAFF and total plasma IgE is still controversial [42-45]. In this study we found no association between soluble BAFF and total IgE when analyzed as continuous variables. Total IgE values were transformed to a categorical variable based on the 75 th percentile in non-asthmatic controls and asthmatic patients as a cut-off to define high total IgE levels but there were no significant differences (Figure 3). In addition, BAFF mRNA levels were not associated with total IgE. Our findings are in agreement with previous studies showing no relationship between BAFF levels and total IgE [43]. Regarding specific IgE to non-parasite/environmental allergens, we found that BAFF levels were not related to specific IgE to $D$. pteronyssinus and $B$. tropicalis, the main sensitizers in this population. There are contradictory published results around this point: it has been reported a significant increase in BAFF levels after allergen exposure in the bronchoalveolar lavage fluid of allergic patients [46] but no relationship was found between soluble BAFF and specific IgE reactivity to fungal allergens [42]. Our results support previous findings detecting association between BAFF variants and specific IgE to Ascaris but not to mites [10]. Some studies have suggested a relationship between BAFF and asthma in humans $[44,47]$. However, in agreement with Lei et al. [48], we found no differences in BAFF between asthmatic patients and controls neither at protein nor at the mRNA levels (Table 1). It is worth mentioning that our results refer to circulating form of the cytokine and its expression in peripheral blood leukocytes. Although several covariates might influence BAFF synthesis, the levels we found in healthy controls were comparable to those observed in other populations [49-51].

\section{$B A F F$ mRNA levels inversely correlate with the cell surface} expression of BAFF receptor (BAFF-R) on B cells

Since there were previous reports showing an inverse relationship between BAFF and BAFF receptor [50,52,53], the expression of membrane-bound BAFF and BAFF- $\mathrm{R}$ was evaluated on PBMCs $(n=113)$. We did not detect cell surface expression of BAFF in gated CD $14^{+}$cells (monocytes), lymphocytes or gated $\mathrm{CD} 19^{+}$cells (B cells); and, as previously described [54], the BAFF-R was highly expressed in peripheral B cells but not in monocytes (Figure 4A). Similar findings were obtained when cell-surface expression of BAFF and BAFF-R were analyzed in sorted monocytes (Figure 4B) and B cells (Figure 4C) from six non-asthmatic controls. As expected [54] we found that plasmablasts $\left(\mathrm{CD} 27^{\text {high }}, \mathrm{CD} 38^{\text {high }}\right)$, switched-memory B cells, mature naïve $B$ cells and transitional $B$ cells expressed BAFF receptor (Additional file 1). The relationship between the cell-surface expression of BAFF-receptor (BAFF-R) on CD $19^{+} \mathrm{B}$ cells (median fluorescence intensity, MFI) with the soluble BAFF levels and the BAFF mRNA levels in PBMCs was evaluated in the subgroup of 113 individuals with flow cytometry data. These observations had a normal distribution in this dataset and therefore parametric tests (Pearson's correlation) were used (Additional file 2). We found a significant inverse correlation between $B A F F 1$ mRNA and the cell surface expression of BAFF-R in CD19 ${ }^{+}$ $\mathrm{B}$ cells $(\mathrm{r}=-0.23, \mathrm{p}=0.01)$, Figure $5 \mathrm{~A}$. This finding was

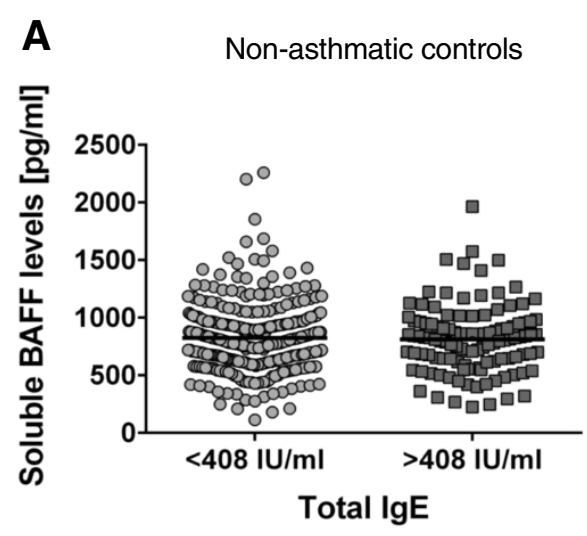

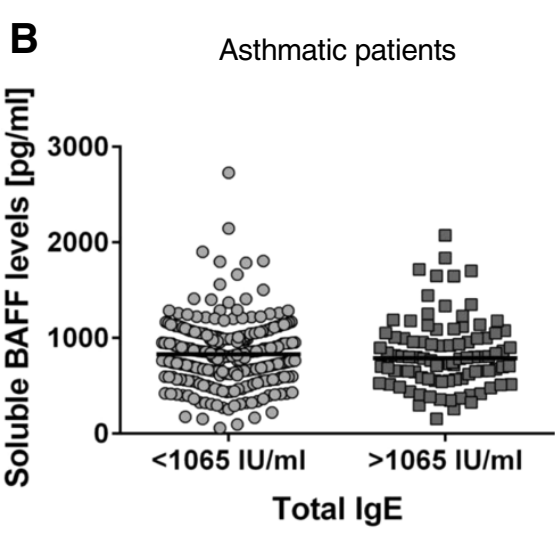

Figure 3

Figure 3 Soluble BAFF levels according to total IgE levels. A. Soluble BAFF levels in non-asthmatic controls according to total IgE below $(n=335)$ or above $(n=113) 75$ th percentile B. Soluble BAFF levels in asthmatics according to total lgE below $(n=277)$ or above $(n=92)$ 75th percentile. 


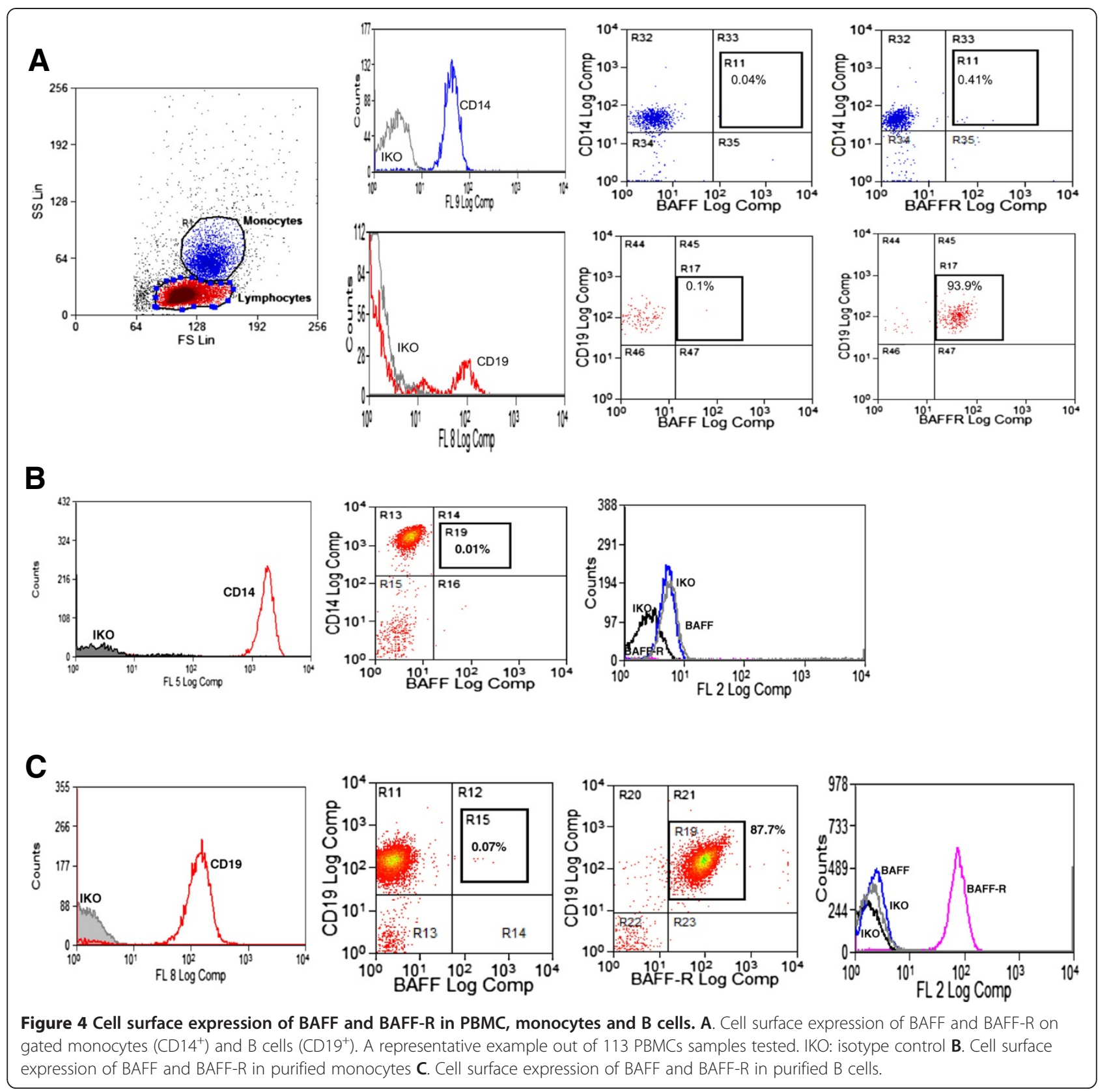

independent of age, gender, disease status and the proportion of monocytes in the sample as tested in a linear regression model. However, no correlation was found with $B A F F 2$ mRNA levels $(\mathrm{r}=-0.13, \mathrm{p}=0.1)$. Regarding protein levels, we found an inverse correlation between soluble BAFF levels and the cell surface expression of BAFF- $R$ in CD19 ${ }^{+} \mathrm{B}$ cells $(r=-0.27, p=0.003)$ Figure $5 B$. These observations were significant after adjustment by age, gender, disease status and the proportion of monocytes in the sample. The inverse relation between soluble BAFF levels and the cell surface expression of BAFF-R has been previously reported in mice and patients with deficiency of BAFF-R [50], patients with systemic lupus erythematous and Sjogren's syndrome [52] hyper-IgE syndrome [53] and acute malaria [37]. In this model, the $8.2 \%$ of the variance in BAFF-R expression can be explained by the soluble BAFF levels. In the context of immune responses to Ascaris, it remains to be elucidated how this BAFF/BAFF-R axis is related to the synthesis of specific antibody levels.

The relationship between circulating soluble BAFF levels and BAFF mRNA levels in blood mononuclear cells

Another question to be addressed was the relationship between soluble BAFF and BAFF mRNA levels, and whether those can serve as proxies for mechanisms contributing to the variation in specific antibody levels. Immune responses 

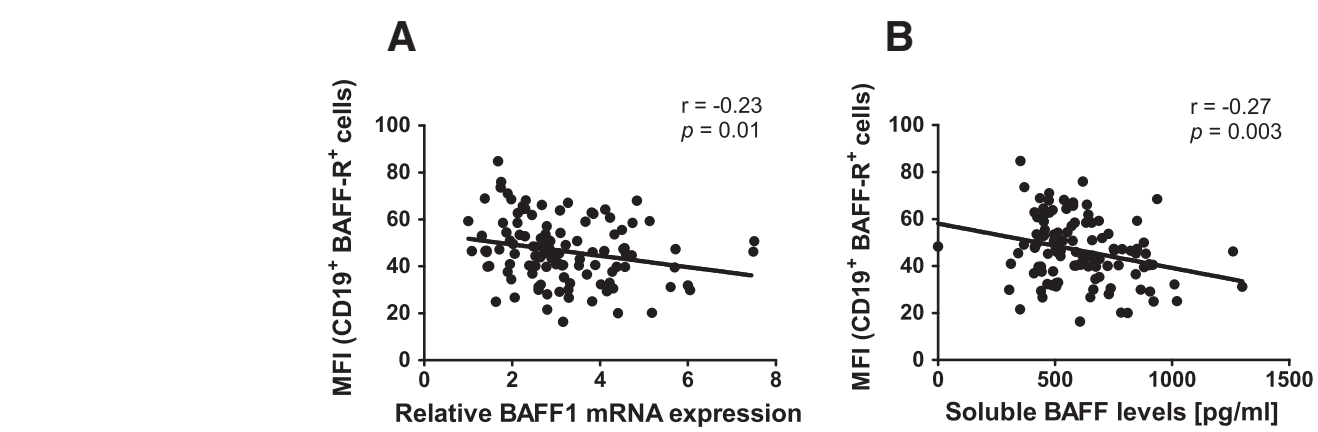

Figure 5 Relationship between cell surface expression of BAFF-R and BAFF levels. A. Correlation between the median fluorescence intensity (MFI) of BAFF-R on gated CD19+ $B$ cells and the mRNA levels for BAFF1 in PBMCs B. Correlation between the MFI of BAFF-R on gated CD19+ $B$ cells and soluble BAFF levels in plasma. The numbers indicate the Pearson correlation coefficient $(r)$ and the p-value (two-tailed). Each dot represents an individual.

to antigens including helminths take place in lymphoid tissues and in infiltrated organs. There, BAFF is produced by many cells including lymphoid tissue stroma cells and resident monocytes $[55,56]$. Levels of circulating soluble BAFF has shown to correlate with local BAFF activity at the germinal center [36]. In this study we found a significant positive correlation $(\mathrm{r}=0.68, \mathrm{p}<0.001)$, between the mRNA levels for BAFF1 (exon 3-4) and BAFF2 (exon 4-6), however, soluble BAFF levels were only significantly correlated to BAFF1 mRNA levels (Figure 6A) and not to BAFF2 mRNA (Figure 6B). From the transcripts to soluble BAFF there are several steps: as a type II transmembrane protein of 285 amino acids (aa) in the plasma membrane, BAFF is cleaved by furine proteases in its $\mathrm{N}$-terminal end (TNFhomology domain) and released in the circulation. There it forms homotrimers of 152 aa amenable to be detected by ELISA; homotrimers can also form other assemblies of less abundance (i.e. BAFF 60 mer) [16,57]. There is another isoform expressed at low levels and called $\triangle \mathrm{BAFF}$ (266 aa), that can form heteromultimers with BAFF (285 aa) and negatively regulate the secretion of the latter [58]. The relation between soluble BAFF levels and BAFF1 mRNA levels could be explained because this transcript contains exon 3, which is informative for both BAFF and $\triangle B A F F$. More studies are needed to elucidate if differential expression of BAFF isoforms contribute to the strength of specific antibody levels.

\section{Conclusions}

Our findings show that soluble BAFF levels are lower in subjects with high specific IgE to Ascaris, suggesting that this cytokine plays a role in the strength of the antibody responses to this nematode and supporting previous molecular genetics studies. Interestingly, soluble BAFF levels are not related with total IgE or IgE sensitization to house dust mites, also in agreement with our previous findings. In addition, we found no differences in BAFF levels between asthmatic patients and controls. As mRNA, BAFF was expressed in mononuclear cells but, as a protein it was not detected in cell-surface including monocytes and B cells. The potential mechanistic link between lower levels of BAFF and the strength of the specific antibodies to Ascaris might be related with the inverse relationship between BAFF levels and the BAFF-R expression on B cells, a receptor that was present at the cell surface in all developmental stages of peripheral B cells including

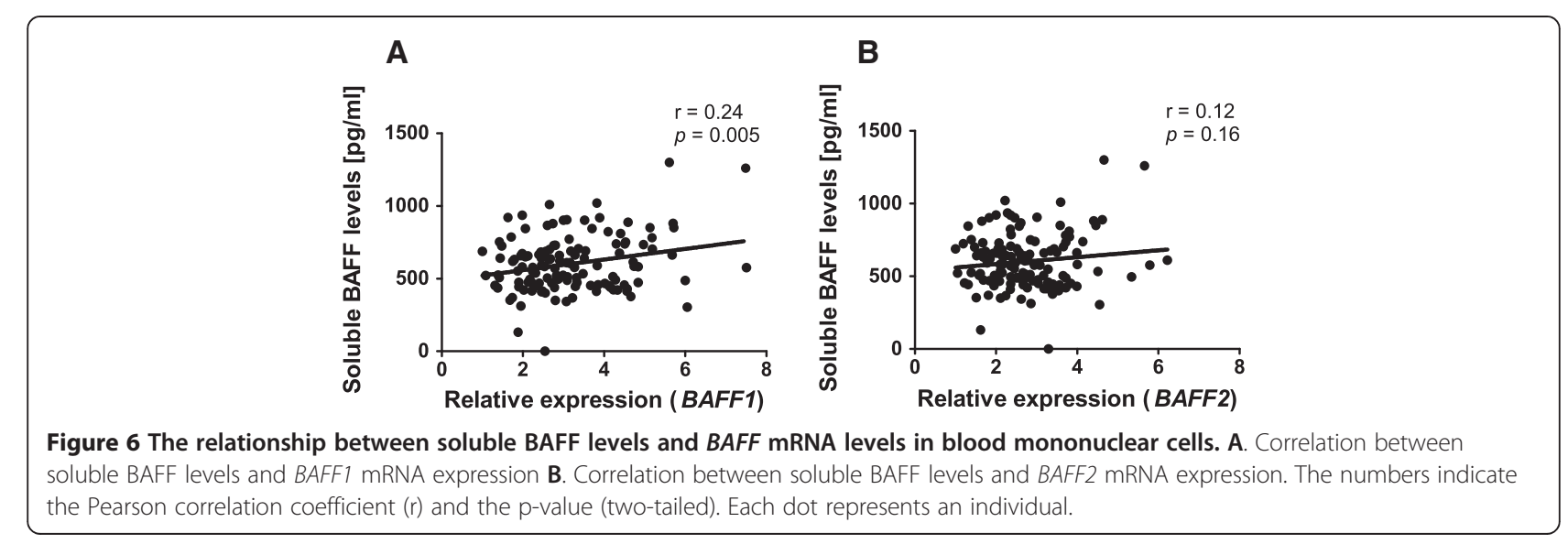


switched memory and plasmablasts. The role of BAFF on the susceptibility to Ascaris infection and its clinical implications deserve further confirmatory and mechanistic studies in larger cohorts.

\section{Methods}

\section{Study design and population}

This is a case-control study performed in Cartagena, Colombia. Eight hundred ninety six subjects including 448 asthmatics and 448 non-related healthy volunteers were selected from a well-characterized dataset [10] and matched by age and gender (Table 1). The matching process was done randomly, without knowledge of antiAscaris IgE or IgG levels. All participants live in an urban, non-industrialized setting, having access to water and electricity and belonging to the lower three (of six) socio-economic strata in the city, where most people are naturally exposed to A. lumbricoides. Measurements of soluble BAFF $(n=896)$ were done in non-previously thawed plasma samples from the repository in which anti-Ascaris antibody determinations were done previously [10]. A random subgroup of these subjects $(\mathrm{n}=$ 131, 71 asthmatics and 60 controls) were visited by a physician of the research staff who obtained $20 \mathrm{~mL}$ blood samples for gene expression, flow cytometry analyses, soluble BAFF, total IgE and specific antibodies to Ascaris and ABA-1. Asthma diagnosis was confirmed according GINA guidelines, including spirometry. Allergic sensitization was defined as a positive IgE result to the mites Dermatophagoides pteronyssinus and/or Blomia tropicalis. The study was approved by the Ethics Committee of the University of Cartagena. A full verbal explanation of the investigation was given and written informed consent was obtained from all participants.

\section{Antibody measurements}

Total IgE was determined by duplicate using an enzymelinked immunosorbent assay (ELISA) kit (RIDASCREEN; R-Biopharm, Darmstadt, Germany) according to the manufacturer's instructions. Specific IgE and IgG to Ascaris extract and ABA-1 as well as specific IgE to mite extracts were detected by ELISA as described previously [10,59]. ABA-1 is a nematode specific allergen from Ascaris (Asc s 1) that is useful for avoiding cross reactivity with mite allergens [59]. Also, antibody responses to ABA-1 have been associated with resistance to ascariasis $[3,5]$. The responses to Ascaris and ABA-1 were analyzed as dichotomous variables, using two cut-off points: the first was the optical density (OD) value of 0.113 (mean OD of six negative, nonallergic, non-parasitized controls +3 standard deviations) which defined sensitized (positive) and non-sensitized (negative) individuals. The second was the 75 th percentile of antibody levels in non-asthmatics individuals (i.e., 0.134 OD units for IgE to Ascaris; 0.154 OD units for IgE to
ABA-1; 2.68 OD units for IgG to Ascaris and 2.11 OD units for IgG to ABA-1). To analyze the strength of total IgE levels the 75th percentile was used as cut-off to define high total IgE phenotype. This percentile was calculated separately in healthy controls $(>75 \mathrm{th}=408.1 \mathrm{IU} / \mathrm{mL})$ and asthmatics $(>75$ th $=1065.8 \mathrm{IU} / \mathrm{mL})$.

\section{Quantification of BAFF levels in plasma}

Soluble BAFF in plasma was measured using a quantitative sandwich enzyme immunoassay according to the manufacturer's instructions (Quantikine Human BAFF/BLyS kit, R\&D Systems Cat. SBLYS0). A standard curve with four parameter logistic (4-PL) curve-fit was used to extrapolate the sample concentration value. Intra assay variation coefficients were lower than $10 \%$. The quantification range of the assay was between 62.5 and $4000 \mathrm{pg} / \mathrm{ml}$.

\section{Isolation of peripheral blood mononuclear cells (PBMCs)} Peripheral blood was diluted 1:2 in $1 \times$ PBS and separated by density gradient using Ficoll Histopaque (Sigma Aldrich, Catalog 1077-1). Tubes were centrifuged during 30 minutes at $400 \mathrm{~g}$ at room temperature and without brake. The layer containing the PBMCs was transferred into a new tube, washed twice with 50 $\mathrm{mL}$ of $1 \times$ PBS and resuspended in $1 \mathrm{~mL}$ of $1 \times$ PBS. A $10 \mu \mathrm{l}$ aliquot was stained with $0.4 \%$ Trypan Blue and counted in a hemocytometer. For gene expression analysis, $1 \times 10^{7}$ cells were placed in a new tube, centrifuged at $300 \mathrm{~g}, 4^{\circ} \mathrm{C}$ during 5 minutes. The supernatant was discarded and the cell pellet homogenized in $750 \mu \mathrm{l}$ of Trizol $^{\odot}$ (Life Technologies) and stored at $-70^{\circ} \mathrm{C}$ until use. The remaining cells were used for flow cytometry analysis (see below).

\section{RNA extraction}

Cell homogenates were thawed during 15 minutes at room temperature (protected from light) and $150 \mu \mathrm{l}$ of chloroform were added to each tube, vigorously mixed by hand and centrifuged at $12000 \mathrm{~g}$ during 15 minutes at $4^{\circ} \mathrm{C}$. The aqueous upper phase was transferred to a fresh tube, diluted in $400 \mu \mathrm{l}$ of $70 \%$ ethanol and pipetted into a spin column (Trizol ${ }^{\odot}$ Plus RNA purification kit, Life Technologies, Catalog: 12183555). Each sample was centrifuged at $12000 \mathrm{~g}$ during 15 seconds at room temperature, the flow-through was discarded and the column containing the RNA washed three times. The spin column was centrifuged at $12000 \mathrm{~g}$ during $1 \mathrm{mi}-$ nute and $50 \mu \mathrm{l}$ of RNAse free water were added for RNA elution (12 $000 g$ during 2 minutes at room temperature). The RNA yield was between $8.1 \mu \mathrm{g}$ and $25 \mu \mathrm{g}$. The A260/A280 ratio ranged from 1.92 to 2.03 and for the ratio A260/A230 from 0.71 to 2.36. Integrity of RNA was also verified by electrophoresis as two intact bands of $28 \mathrm{~S}$ and $18 \mathrm{~S}$ ribosomal RNA. 


\section{cDNA synthesis}

cDNA was synthesized from $1 \mu \mathrm{g}$ of total RNA using the Superscript III first strand super mix kit (Invitrogen, Cata$\log 11752050)$ following manufacturer's instructions. RTPCR reactions included retrotranscriptase, reaction mix (oligodT $22.5 \mu \mathrm{M}$, random hexamers $2.5 \mathrm{ng} / \mu \mathrm{l}, 10 \mathrm{mM}$ $\mathrm{MgCl}_{2}$ and dNTPs), total RNA and RNAse-free water (Ambion Cat. AM9937). The synthesized cDNA was diluted with $80 \mu \mathrm{l}$ of water and stored at $-20^{\circ} \mathrm{C}$ until amplification. cDNA was genomic-DNA free, confirmed by an amplification reaction using a non retrotranscriptase enzyme control (RT-minus control).

\section{Quantitative PCR}

BAFF mRNA was detected by quantitative PCR (qPCR) using Taqman gene expression assays on a 7300 Real-Time Polymerase Chain Reaction (PCR) system (Applied Biosystems, Foster City, CA, USA). To detect differential splicing, the mRNA was measured in two separated assays: assay 1 targeting the exons 3 and 4 (Cat. Hs00198106, 84 bp amplicon) and assay 2 targeting the boundaries of exons 4-5 and 5-6 (Cat. Hs00902574, 73 bp amplicon). The two isoforms were named BAFF1 and BAFF2 (Additional file 3). Expression of $\beta 2$ micro-globulin was used as endogenous control (Cat. Hs00984230, 81bp amplicon). Each sample was tested by duplicate and the average $C_{T}$ value exported from the SDS Software (Applied Biosystems). The $C_{T}$ value of the $\beta 2 \mathrm{M}$ gene (Mean $C_{\mathrm{T}} 18.8 \pm 0.40 \mathrm{SD}$ ) was subtracted from the $C_{\mathrm{T}}$ values of the target genes (Mean $\mathrm{C}_{\mathrm{T}} 25.7 \pm 0.60 \mathrm{SD}$ for $B A F F 1$ and Mean $\mathrm{C}_{\mathrm{T}} 27.1 \pm 0.67 \mathrm{SD}$ for $\left.B A F F 2\right)$. The normalized value was expressed as the delta $C_{t}(\Delta C t=$ $\left.\mathrm{Ct}_{\mathrm{BAFF}}-\mathrm{Ct}_{\mathrm{B} 2 \mathrm{M}}\right)$. The highest $\Delta \mathrm{C}_{\mathrm{T}}$ value among all samples was subtracted from each sample and the resulting number expressed as the delta-delta $C_{\mathrm{T}}$. Relative expression levels were calculated as $2^{\wedge-(\Delta \Delta C T)}$ [60]. The probes for BAFF were FAM-labeled and for $\beta 2$ micro-globulin were VIC-labeled, all assays included NFQ (non- fluorescent quencher).

\section{Flow cytometry on PBMCs}

Cell surface expression of BAFF and BAFF-R was analyzed on PBMCs by flow cytometry $(n=113)$. Cells were resuspended in MACS buffer (0.5\% BSA in PBS) at a final concentration of $10^{5}$ cells $/ 100 \mu \mathrm{l}$ per tube. Fc $\gamma$ receptors were blocked with $1 \mu \mathrm{l}$ of normal mouse serum (e-Bioscience, Catalog 24-5544) during 10 minutes at $4^{\circ} \mathrm{C}$. A panel of fluorochrome-conjugated monoclonal antibodies (APCeFluor $\alpha$-human CD14, Catalog: 47-0149; APC $\alpha$-human CD19, Catalog 17-0199; PE $\alpha$-human BAFF/BLyS, Catalog 12-9017 and FITC $\alpha$-human BR3/BAFF-R, Catalog 119117, all from e-Bioscence) were added to the cells and incubated 30 minutes at $4^{\circ} \mathrm{C}$ protected from light. Each assay included the unstained sample and a panel of appropriate isotype controls to set the gates of positive and negative populations. After staining, cells were washed twice with PBS and resuspended in $500 \mu$ l of PBS. Data on 20000 events per sample were acquired using a Dako Cytomation Cytometer (Beckman Coulter, Inc. CA, USA) and analyzed by Summit 4.3 (Beckman Coulter, Inc. CA, USA). Electronic gating was used to evaluate the expression of BAFF and BAFF-R in CD14 ${ }^{+}$cells and $\mathrm{CD} 19^{+} \mathrm{B}$ cells.

\section{Flow cytometry in purified monocytes and B cells}

Peripheral blood monocytes and B cells were purified by magnetic associated cell sorting (MACS) using negative selection protocols (Monocyte Isolation kit catalog 130091-153 and B cells isolation kit catalog 130-091-151, Miltenyi Biotec). Briefly, $30 \times 10^{6} \mathrm{PBMCs}$ were resuspended in MACS buffer containing $0.5 \%$ BSA - PBS pH 7.2. Then, biotin-conjugated antibody cocktails were added and the mixture incubated by 10 minutes at $4^{\circ} \mathrm{C}$. Non target cells were magnetically labeled with a cocktail of monoclonal antibodies targeting CD2, CD14, CD16, CD36, CD43 and CD235a for the B cell separation protocol and CD3, CD7, CD16, CD19, CD56, CD123 and CD235a for the monocyte separation protocol (Miltenyi Biotec). Antibiotin microbeads were added and the cells incubated by 15 minutes at $4^{\circ} \mathrm{C}$. After washing, cells were resuspended in MACS buffer at a final volume of $500 \mu \mathrm{l}$ and passed through the column. The flow-through was collected and centrifuged at $300 \mathrm{~g}$ during 5 minutes at $4^{\circ} \mathrm{C}$. The supernatant was discarded, and the cells reconstituted in $500 \mu \mathrm{l}$ of MACS buffer and counted. Purified cells were stained with specific antibodies to detect BAFF and BAFF-R in different subpopulations (Additional file 4). The purity of monocytes and B cells was $91 \%$ and $90 \%$ respectively.

\section{Statistics}

Statistical analyses were performed using the statistical package for the social sciences software (SPSS version 17 for Windows; SPSS Inc., Chicago, IL, USA) and GraphPad Prism software v.5. Bivariate correlations were used to analyze the relationship between soluble BAFF and the antibody levels as continuous variables; since soluble BAFF was non-normally distributed, the non-parametric Spearman test was used. IgG levels were normally distributed therefore soluble BAFF levels were transformed to their square root to achieve normality and the Pearson correlation test was applied for this isotype. The comparisons of soluble BAFF between the groups of antibody responders $(<75$ th and $>75$ th) were done using Mann-Whitney $U$ test (p-values presented after 10000 permutations). Linear regression was then used to model the effect of antibody grouping on transformed soluble BAFF levels adjusting by age, gender and disease status (asthma yes/no). Since $B A F F$ mRNA values in PBMCs were normally distributed (Additional file 2), the comparison between groups of antibody responders $(<75$ th and $>75$ th) were done by 
independent samples $t$ test and further verified by adjusted linear regression models. MFI of BAFF-R was also normally distributed and its relationship with soluble BAFF and transcript levels were explored using Pearson correlation test. Since BAFF transcripts were measured in unfractionated mononuclear cells, the percentage of monocytes per sample was included as covariate in adjusted linear models. The relationship between soluble BAFF levels and the mRNA levels of the transcripts $B A F F 1$ and $B A F F 2$ was analyzed using Pearson correlation test. A p value $\leq 0.05$ (two-tailed) was considered statistically significant.

\section{Additional files}

\section{Additional file 1: Cell surface expression of BAFF-R in subpopula- tions of purified B cells. \\ Additional file 2: Distribution of the median intensity levels of BAFF-R in B cells, soluble BAFF levels and mRNA levels in PBMCs for the subgroup of 113 individuals. \\ Additional file 3: Schematic representation of the gene encoding BAFF and the exons covered by the gene expression assays. \\ Additional file 4: Antibodies used for flow cytometry in PBMCs, monocytes and B cells.}

\section{Competing interests}

The authors declare that they have no competing interests.

\section{Authors' contributions}

$A B, N A$ performed experiments and statistical analyses; DM performed antibody measurements; NA participated in the study design and supervised data analysis. LC conceived the investigation and supervised the general aspects of the work and data analyses. AB, NA, LC wrote the manuscript. All authors read and approved the final version of the manuscript.

\section{Acknowledgements}

We thank all the patients and controls for their voluntary participation in the study; also to our scientific collaborators at the Genetics and Molecular Biology Group (University of Cartagena, Colombia) for the infrastructure support to perform the cell isolations. We also thank Dr. Malcolm Kennedy (University of Glasgow) for providing the ABA-1. This work was funded by the Administrative Department of Science, Technology and Innovation (Colciencias, Colombia) Grant 680-2009; and by the University of Cartagena, Colombia. AB received funds from Fundemeb. The funders had no role in study design, data collection and analysis, decision to publish, or preparation of the manuscript.

Received: 7 January 2014 Accepted: 2 June 2014

Published: 7 June 2014

\section{References}

1. Acevedo N, Caraballo L: IgE cross-reactivity between Ascaris lumbricoides and mite allergens: possible influences on allergic sensitization and asthma. Parasite Immunol 2011, 33(6):309-321.

2. Hagel I, Cabrera M, Buvat E, Gutierrez L, Santaella C, Borges R, Infante B, Salas MC, Barrios Y: Antibody responses and resistance against Ascaris lumbricoides infection among Venezuelan rural children: the influence of ethnicity. J Trop Pediatr 2008, 54(5):354-356.

3. Turner JD, Faulkner H, Kamgno J, Kennedy MW, Behnke J, Boussinesq M, Bradley JE: Allergen-specific lgE and lgG4 are markers of resistance and susceptibility in a human intestinal nematode infection. Microbes Infect 2005, 7(7-8):990-996.

4. Hagel I, Lynch NR, Di Prisco MC, Rojas E, Perez M, Alvarez N: Ascaris reinfection of slum children: relation with the lgE response. Clin Exp Immunol 1993, 94(1):80-83.
5. McSharry C, Xia Y, Holland CV, Kennedy MW: Natural immunity to Ascaris lumbricoides associated with immunoglobulin $E$ antibody to ABA-1 allergen and inflammation indicators in children. Infect Immun 1999, 67(2):484-489.

6. Dold C, Holland CV: Investigating the underlying mechanism of resistance to Ascaris infection. Microbes Infect 2011, 13(7):624-631.

7. Kennedy MW, Tomlinson LA, Fraser EM, Christie JF: The specificity of the antibody response to internal antigens of Ascaris: heterogeneity in infected humans, and $\mathrm{MHC}(\mathrm{H}-2)$ control of the repertoire in mice. Clin Exp Immunol 1990, 80(2):219-224.

8. Williams-Blangero S, VandeBerg JL, Subedi J, Aivaliotis MJ, Rai DR, Upadhayay RP, Jha B, Blangero J: Genes on chromosomes 1 and 13 have significant effects on Ascaris infection. Proc Natl Acad Sci U S A 2002, 99(8):5533-5538.

9. Williams-Blangero S, Vandeberg $J$, Subedi J, Jha B, Correa-Oliveira R, Blangero J: Localization of multiple quantitative trait loci influencing susceptibility to infection with Ascaris lumbricoides. J Infect Dis 2008, 197(1):66-71.

10. Acevedo N, Mercado D, Vergara C, Sanchez J, Kennedy MW, Jimenez S, Fernandez AM, Gutierrez M, Puerta L, Caraballo L: Association between total immunoglobulin $\mathrm{E}$ and antibody responses to naturally acquired Ascaris lumbricoides infection and polymorphisms of immune system-related LIG4, TNFSF13B and IRS2 genes. Clin Exp Immunol 2009, 157(2):282-290.

11. Mariette $X$, Roux S, Zhang J, Bengoufa D, Lavie F, Zhou T, Kimberly R: The level of BLyS (BAFF) correlates with the titre of autoantibodies in human Sjogren's syndrome. Ann Rheum Dis 2003, 62(2):168-171.

12. Ng LG, Sutherland AP, Newton R, Qian F, Cachero TG, Scott ML, Thompson JS, Wheway J, Chtanova T, Groom J, Sutton IJ, Xin C, Tangye SG, Kalled SL, Mackay F, Mackay CR: B cell-activating factor belonging to the TNF family (BAFF)-R is the principal BAFF receptor facilitating BAFF costimulation of circulating T and B cells. J Immunol 2004, 173(2):807-817.

13. Vincent FB, Saulep-Easton D, Figgett WA, Fairfax KA, Mackay F: The BAFF/ APRIL system: emerging functions beyond $B$ cell biology and autoimmunity. Cytokine Growth Factor Rev 2013, 24(3):203-215.

14. Scapini P, Nardelli B, Nadali G, Calzetti F, Pizzolo G, Montecucco C, Cassatella MA: G-CSF-stimulated neutrophils are a prominent source of functional BLyS. J Exp Med 2003, 197(3):297-302.

15. Huard B, Arlettaz L, Ambrose C, Kindler V, Mauri D, Roosnek E, Tschopp J, Schneider $P$, French LE: BAFF production by antigen-presenting cells provides T cell co-stimulation. Int Immunol 2004, 16(3):467-475.

16. Mackay F, Schneider P: Cracking the BAFF code. Nat Rev Immunol 2009, 9(7):491-502.

17. Alsaleh G, Messer L, Semaan N, Boulanger N, Gottenberg JE, Sibilia J, Wachsmann D: BAFF synthesis by rheumatoid synoviocytes is positively controlled by alpha5beta 1 integrin stimulation and is negatively regulated by tumor necrosis factor alpha and Toll-like receptor ligands. Arthritis Rheum 2007, 56(10):3202-3214.

18. Schneider P, MacKay F, Steiner V, Hofmann K, Bodmer JL, Holler N, Ambrose C, Lawton P, Bixler S, Acha-Orbea H, Valmori D, Romero P, Werner-Favre C, Zubler RH, Browning JL, Tschopp J: BAFF, a novel ligand of the tumor necrosis factor family, stimulates B cell growth. J Exp Med 1999, 189(11):1747-1756.

19. Shapiro-Shelef M, Calame K: Regulation of plasma-cell development. Nat Rev Immunol 2005, 5(3):230-242.

20. Thompson JS, Bixler SA, Qian F, Vora K, Scott ML, Cachero TG, Hession C, Schneider P, Sizing ID, Mullen C, Strauch K, Zafari M, Benjamin CD, Tschopp J, Browning $J$, Ambrose C: BAFF-R, a newly identified TNF receptor that specifically interacts with BAFF. Science 2001, 293(5537):2108-2111.

21. Thompson JS, Schneider P, Kalled SL, Wang L, Lefevre EA, Cachero TG, MacKay F, Bixler SA, Zafari M, Liu ZY, Woodcock SA, Qian F, Batten M, Madry C, Richard Y, Benjamin CD, Browning JL, Tsapis A, Tschoop J, Ambrose C: BAFF binds to the tumor necrosis factor receptor-like molecule $B$ cell maturation antigen and is important for maintaining the peripheral $B$ cell population. J Exp Med 2000, 192(1):129-135.

22. Litinskiy MB, Nardelli B, Hilbert DM, He B, Schaffer A, Casali P, Cerutti A: DCs induce CD40-independent immunoglobulin class switching through BLyS and APRIL. Nat Immunol 2002, 3(9):822-829.

23. Castigli E, Wilson SA, Scott S, Dedeoglu F, Xu S, Lam KP, Bram RJ, Jabara H, Geha RS: TACl and BAFF-R mediate isotype switching in B cells. J Exp Med 2005, 201(1):35-39.

24. Xu W, He B, Chiu A, Chadburn A, Shan M, Buldys M, Ding A, Knowles DM, Santini PA, Cerutti A: Epithelial cells trigger frontline immunoglobulin 
class switching through a pathway regulated by the inhibitor SLPI. Nat Immunol 2007, 8(3):294-303.

25. Araujo RN, Padilha T, Zarlenga D, Sonstegard T, Connor EE, Van Tassel C, Lima WS, Nascimento E, Gasbarre LC: Use of a candidate gene array to delineate gene expression patterns in cattle selected for resistance or susceptibility to intestinal nematodes. Vet Parasitol 2009, 162(1-2):106-115.

26. Webster LM, Mello LV, Mougeot F, Martinez-Padilla J, Paterson S, Piertney $S B$ : Identification of genes responding to nematode infection in red grouse. Mol Ecol Resour 2011, 11(2):305-313.

27. Bermejo DA, Amezcua-Vesely MC, Montes CL, Merino MC, Gehrau RC, Cejas $H$, Acosta-Rodriguez EV, Gruppi A: BAFF mediates splenic B cell response and antibody production in experimental Chagas disease. PLoS Negl Trop Dis 2010, 4(5):e679.

28. Scholzen A, Sauerwein RW: How malaria modulates memory: activation and dysregulation of B cells in Plasmodium infection. Trends Parasitol 2013, 29(5):252-262.

29. Acevedo N, Erler A, Briza P, Puccio F, Ferreira F, Caraballo L: Allergenicity of Ascaris lumbricoides tropomyosin and IgE sensitization among asthmatic patients in a tropical environment. Int Arch Allergy Immunol 2011, 154(3):195-206.

30. Dold C, Holland CV: Ascaris and ascariasis. Microbes Infect 2011, 13(7):632-637.

31. Lopez De Padilla CM, McNallan KT, Crowson CS, Bilgic H, Bram RJ, Hein MS, Ytterberg SR, Amin S, Peterson EJ, Baechler EC, Reed AM: BAFF expression correlates with idiopathic inflammatory myopathy disease activity measures and autoantibodies. J Rheumatol 2013, 40(3):294-302.

32. Cheema GS, Roschke V, Hilbert DM, Stohl W: Elevated serum B lymphocyte stimulator levels in patients with systemic immune-based rheumatic diseases. Arthritis Rheum 2001, 44(6):1313-1319.

33. Pers JO, Daridon C, Devauchelle V, Jousse S, Saraux A, Jamin C, Youinou P: BAFF overexpression is associated with autoantibody production in autoimmune diseases. Ann N Y Acad Sci 2005, 1050:34-39.

34. Bosello S, Youinou P, Daridon C, Tolusso B, Bendaoud B, Pietrapertosa D, Morelli A, Ferraccioli G: Concentrations of BAFF correlate with autoantibody levels, clinical disease activity, and response to treatment in early rheumatoid arthritis. J Rheumatol 2008, 35(7):1256-1264.

35. Thibault-Espitia A, Foucher Y, Danger R, Migone T, Pallier A, Castagnet S, G-Gueguen C, Devys A, C-Gautier A, Giral M, Soulillou JP, Brouard S: BAFF and BAFF-R levels are associated with risk of long-term kidney graft dysfunction and development of donor-specific antibodies. Am J Transplant 2012, 12(10):2754-2762.

36. Goenka R, Matthews AH, Zhang B, O'Neill PJ, Scholz JL, Migone TS, Leonard WJ, Stohl W, Hershberg U, Cancro MP: Local BLyS production by T follicular cells mediates retention of high affinity B cells during affinity maturation. J Exp Med 2014, 211(1):45-56

37. Nduati E, Gwela A, Karanja H, Mugyenyi C, Langhorne J, Marsh K, Urban BC The plasma concentration of the $B$ cell activating factor is increased in children with acute malaria. J Infect Dis 2011, 204(6):962-970.

38. Geiger SM, Massara CL, Bethony J, Soboslay PT, Carvalho OS, Correa-Oliveira R: Cellular responses and cytokine profiles in Ascaris lumbricoides and Trichuris trichiura infected patients. Parasite Immunol 2002, 24(11-12):499-509.

39. Nowlan ML, Drewe E, Bulsara H, Esposito N, Robins RA, Tighe PJ, Powell RJ, Todd I: Systemic cytokine levels and the effects of etanercept in TNF receptor-associated periodic syndrome (TRAPS) involving a C33Y mutation in TNFRSF1A. Rheumatology 2006, 45(1):31-37.

40. Williams-Blangero S, Fenstad MH, Kumar S, Blangero J: Genetics of Human Host Susceptibility to Ascariasis. In Ascaris: The Neglected Parasite. Edited by Holland C. London: Elsevier; 2013:315-340.

41. Zhou L, Zhong R, Hao W, Wang H, Fan X, Zhang L, Mi Q: Interleukin-10 and interferon-gamma up-regulate the expression of B-cell activating factor in cultured human promyelocytic leukemia cells. Exp Mol Pathol 2009, 87(1):54-58.

42. Chen Y, Lind Enoksson S, Johansson C, Karlsson MA, Lundeberg L, Nilsson G, Scheynius A, Karlsson MC: The expression of BAFF, APRIL and TWEAK is altered in eczema skin but not in the circulation of atopic and seborrheic eczema patients. PLoS One 2011, 6(7):e22202.

43. Lied GA, Lillestol K, Valeur J, Berstad A: Intestinal B cell-activating factor: an indicator of non-lgE-mediated hypersensitivity reactions to food? Aliment Pharmacol Ther 2010, 32(1):66-73.

44. Kang JS, Yoon YD, Ahn JH, Kim SC, Kim KH, Kim HM, Moon EY: B cellactivating factor is a novel diagnosis parameter for asthma. Int Arch Allergy Immunol 2006, 141(2):181-188.
45. Jee HM, Kim KW, Hong JY, Sohn MH, Kim KE: Increased serum B cellactivating factor level in children with atopic dermatitis. Clin Exp Dermatol 2010, 35(6):593-598.

46. Kato A, Xiao H, Chustz RT, Liu MC, Schleimer RP: Local release of B cellactivating factor of the TNF family after segmental allergen challenge of allergic subjects. J Allergy Clin Immunol 2009, 123(2):369-375.

47. Jee HM, Choi BS, Kim KW, Sohn MH, Han MY, Kim KE: Increased B cellactivating factor (BAFF) level in the sputum of children with asthma. Korean J Pediatr 2010, 53(8):795-800.

48. Lei Z, Liu G, Huang Q, Lv M, Zu R, Zhang GM, Feng ZH, Huang B: SCF and IL-31 rather than IL-17 and BAFF are potential indicators in patients with allergic asthma. Allergy 2008, 63(3):327-332.

49. Migita K, Abiru S, Maeda Y, Nakamura M, Komori A, Ito M, Fujiwara S, Yano $\mathrm{K}$, Yatsuhashi $\mathrm{H}$, Eguchi K, Ishibashi H: Elevated serum BAFF levels in patients with autoimmune hepatitis. Hum Immunol 2007, 68(7):586-591.

50. Kreuzaler M, Rauch M, Salzer U, Birmelin J, Rizzi M, Grimbacher B, Plebani A, Lougaris V, Quinti I, Thon V, Litzman J, Schlesier M, Warnatz K, Thiel J, Rolink $A G$, Eibel $H$ : Soluble BAFF levels inversely correlate with peripheral B cell numbers and the expression of BAFF receptors. J Immunol 2012, 188(1):497-503.

51. Matharu K, Zarember KA, Marciano BE, Kuhns DB, Spalding C, Garofalo M, Dimaggio T, Estwick T, Huang CY, Fink D, Priel DL, Fleisher TA, Holland SM, Malech HL, Gallin Jl: B-cell activating factor (BAFF) is elevated in chronic granulomatous disease. Clin Immunol 2013, 148(2):258-264.

52. Sellam J, Miceli-Richard C, Gottenberg JE, Ittah M, Lavie F, Lacabaratz C, Gestermann N, Proust A, Lambotte O, Mariette X: Decreased B cell activating factor receptor expression on peripheral lymphocytes associated with increased disease activity in primary Sjogren's syndrome and systemic lupus erythematosus. Ann Rheum Dis 2007, 66(6):790-797.

53. Meyer-Bahlburg A, Renner ED, Rylaarsdam S, Reichenbach J, Schimke LF, Marks A, Tcheurekdjian H, Hostoffer R, Brahmandam A, Torgerson TR, Belohradsky BH, Rawlings DJ, Ochs HD: Heterozygous signal transducer and activator of transcription 3 mutations in hyper-IgE syndrome result in altered B-cell maturation. J Allergy Clin Immunol 2012, 129(2):559-562. 562 e551-552.

54. Schneider P: The role of APRIL and BAFF in lymphocyte activation. Curr Opin Immunol 2005, 17(3):282-289.

55. Tertilt C, Joh J, Krause A, Chou P, Schneeweiss K, Crystal RG, Worgall S: Expression of B-cell activating factor enhances protective immunity of a vaccine against Pseudomonas aeruginosa. Infect Immun 2009, 77(7):3044-3055.

56. Gorelik L, Gilbride K, Dobles M, Kalled SL, Zandman D, Scott ML: Normal B cell homeostasis requires $B$ cell activation factor production by radiation-resistant cells. J Exp Med 2003, 198(6):937-945.

57. Cachero TG, Schwartz IM, Qian F, Day ES, Bossen C, Ingold K, Tardivel A, Krushinskie D, Eldredge J, Silvian L, Lugovskoy A, Farrington GK, Strauch K, Schneider $P$, Whitty A: Formation of virus-like clusters is an intrinsic property of the tumor necrosis factor family member BAFF (B cell activating factor). Biochemistry 2006, 45(7):2006-2013.

58. Gavin AL, Ait-Azzouzene D, Ware CF, Nemazee D: DeltaBAFF, an alternate splice isoform that regulates receptor binding and biopresentation of the B cell survival cytokine, BAFF. J Biol Chem 2003, 278(40):38220-38228.

59. Acevedo N, Sanchez J, Erler A, Mercado D, Briza P, Kennedy M, Fernandez A, Gutierrez M, Chua KY, Cheong N, Jiménez S, Puerta L, Caraballo L: IgE crossreactivity between Ascaris and domestic mite allergens: the role of tropomyosin and the nematode polyprotein ABA-1. Allergy 2009, 64(11):1635-1643.

60. Livak K, Schmittgen TD: Analysis of relative gene expression data using real-time quantitative PCR and the 2(-Delta Delta C(T)) Method. Methods 2001, 25(4):402-408.

doi:10.1186/1471-2172-15-22

Cite this article as: Bornacelly et al: The strength of the antibody response to the nematode Ascaris lumbricoides inversely correlates with levels of B-Cell Activating Factor (BAFF). BMC Immunology 2014 15:22. 